\begin{tabular}{|c|l}
\hline Construction and Material Journal & $\begin{array}{l}\text { Volume 1 No.1 } \\
\text { Maret 2019 }\end{array}$ \\
\hline
\end{tabular}

\title{
PEMANFAATAN LIMBAH GENTENG BETON PADA PAVING BLOCK
}

\author{
Pratikto $^{(1)}$, Ginanjar $\mathbf{A}^{(2)}$ \\ 1,2 Jurusan Teknik Sipil, Program Studi Teknik Konstruksi Gedung, Politeknik Negeri Jakarta, Jl. Prof, \\ Dr, G. A. Siwabessy, Kampus Baru UI Depok 16425, Telepon/Fax : (021)-7270036 Ext.218, email: \\ pratikto@sipil.pnj.ac.id,.Alifahginanjar738@gmail.com
}

\begin{abstract}
ABSTRAK
Paving block merupakan bahan bangunan yang digunakan sebagai pekerasan permukaan jalan, baik jalan untuk keperluan parkir kendaraan ataupun jalan raya, ataupun untuk keperluan dekoratif pada pembuatan taman. Bahan penyusun paving block adalah semen, pasir dan air dengan atau tanpa bahan tambah lainnya. Bahan tambah yang digunakan dapat berupa limbah atau sisa bahan bangunan yang tidak terpakai. Penggunaan limbah bertujuan untuk mendapatkan mutu paving block sesuai standard dan memanfaatkan limbah secara optimal. Limbah genteng beton banyak ditemukan di sekitar bangunan bertingkat yang sudah lama dan khususnya kampus Politeknik Negeri Jakarta.Limbah ini dapat digunakan sebagai bahan pembentuk paving block sebagai substitusi agregat kasar. Dalam penelitian ini digunakan perbandingan semen dan pasir adalah $1: 3$ dengan presentase limbah genteng beton sebesar $0 \%, 10 \%$, $20 \%, 30 \%$, dan $40 \%$. Nilai fas yang digunakan adalah 0,35 . Hasil pengujian nilai kuat tekan yang ditinjau pada hari ke 7 pada presentase $0 \%$ sebesar 52,59 Mpa, presentase 10\% sebesar 44,949 Mpa, presentase $20 \%$ sebesar 40,942 Mpa, presentase 30\% sebesar 40,685 Mpa dikategorikan mutu A, sedangkan presentase $40 \%$ sebesar $26 \mathrm{MPa}$ dikategorikan mutu B.
\end{abstract}

Kata kunci: paving block, Limbah genteng beton, agregat kasar

\section{ABSTRACT}

Paving block is a material that is used as a road surface hardening, either for vehicle parking, highways, or for decorative purposes in gardening. The constituent material of paving blocks are cement, sand and water with or without other added material. The added material used can be in the form of waste or residual unused building materials. The use of waste building material of concrete tile aims to get the quality of paving blocks according to standards and utilize waste optimally. Waste concrete roof tiles can be found around many high-rise building constructions and especially Jakarta State Polytechnic campus. This waste can be used as a paving block as a rough aggregate substitute. In this study the ratio of cement and sand was 1: 3 with a percentage of concrete tile waste of $0 \%, 10 \%, 20 \%, 30 \%$, and $40 \%$. The fas value used is 0.35. The testing results of compressive strength which is reviewed on day 7 at a percentage of $0 \%$ of $52.59 \mathrm{MPa}, 10 \%$ of $44.949 \mathrm{MPa}, 20 \%$ of $40.942 \mathrm{MPa}, 30 \%$ of $40.658 \mathrm{MPa}$ are categorized as grade A, while at a percentage of $40 \%$ the compressive strength is $26 \mathrm{MPa}$ which is categorized as grade $B$.

Keywords: paving block, waste concrete tile, coarse aggregate

\section{PENDAHULUAN}

Pertumbuhan penduduk yang sangat tinggi pada kota-kota besar di Indonesia mengakibatkan tingginya kebutuhan akan sarana transportasi. Pembangunan infrastruktur seperti gedung, sarana perhubungan serta infrastruktur lainnya, menggunakan paving block sebagai salah satu komponen nya, seperti pembuatan halaman rumah tinggal, halaman kantor, garasi atau tempat parkir dan lain sebagainya. Paving block terbuat dari campuran bahan semen atau pengikat hidrolis atau sejenisnya 
dengan agregat halus, agregat kasar dan dengan atau tanpa bahan tambah lainnya yang dicetak sedemikian rupa berbentuk block yang akan dirangkai ditempat[1].

Adapun bahan tambah yang digunakan dapat berupa limbah atau sisa-sisa bahan bangunan yang tidak terpakai. Limbah genteng beton merupakan salah satu jenis limbah sisa bahan konstruksi yang berasal dari lingkungan kampus Politeknik Negeri Jakarta, yaitu di daerah (a) parkir TGP , (b) gedung B , di lokasi parkir utama (c), dan di (d) laboratorium teknik sipil . Limbah ini akan digunakan sebagai bahan pembentuk paving block dan akan dimanfaatkan secara optimal untuk paving block sehingga tidak ada bahan dari beton yang terbuang.

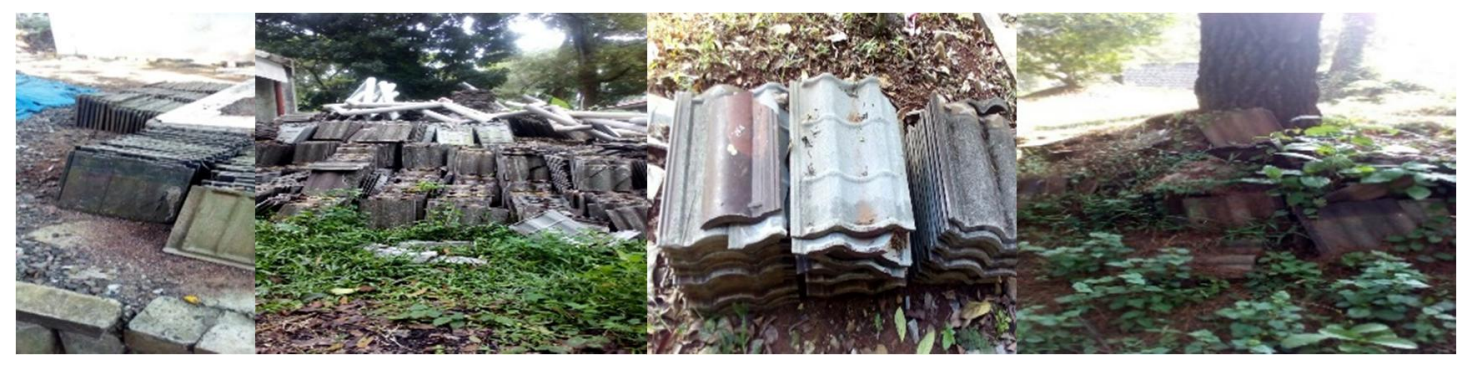

Gambar 1. Limbah genteng beton di lingkungan PNJ.

Limbah ini akan digunakan sebagai material pembentuk paving block dengan komposisi untuk campuran paving block tertentu. Hasil yang didapatkan akan mengikuti standard paving block menurut SNI.

Adapun Standar mutu yang harus dipenuhi paving block untuk lantai menurut [2] adalah sebagai berikut :

1. Paving block untuk lantai harus mempunyai bentuk yang sempurna, tidak terdapat retak-retak dan cacat, bagian sudut dan rusuknya tidak mudah direpihkan dengan kekuatan jari tangan.

2. Tebal nominal adalah $60 \mathrm{~mm}$ dan penyimpangan tebal paving block untuk lantai diperkenankan kurang lebih $3 \mathrm{~mm}$

3. Paving block untuk lantai harus mempunyai kekuatan fisik tabel 1 , sebagai berikut

Tabel 1. Kekuatan Fisik Paving Block

\begin{tabular}{llll}
\hline & \multicolumn{3}{c}{ Kuat Tekan(Mpa) } \\
Mutu & Rerata & Min & \multicolumn{1}{c}{ Ket } \\
\hline A & 40 & 35 & Jalan \\
B & 20 & 17 & Parkir \\
C & 15 & 12,5 & Pejalan kaki \\
D & 10 & 8,5 & taman \\
\hline
\end{tabular}

Kuat tekan adalah Gaya persatuan luas permukaan paving block $=\mathrm{P} / \mathrm{A}$, dimana $\mathrm{P}$ adalah gaya $(\mathrm{N})$ dan luas permukaan adalah $\mathrm{mm} 2$.

Rumusan masalah dalam penulisan ini adalah : Berapakah nilai komposisi dari masing2 bahan pembentuk paving block ini? Apakah masih dapat masuk pada SNI untuk paving block? 
Penelitian ini bertujuan untuk : mendapatkan presentase dari limbah genting beton terhadap agregat kasar yang optimal dilihat dari hasil nilai kuat tekan pada variasi sebesar $0 \%$ hingga $40 \%$. Tujuan lain adalah untuk mendapatkan daya serap air seperti yang disyaratkan oleh SNI.

Hasil yang didapatkan ini diharapkan dapat memberi manfaat bagi perkembangan ilmu pengetahuan dan masyarakat, diantaranya adalah :

a. Sebagai salah satu sumbangan dalam pengembangan ilmu pengetahuan sehingga menambah wawasan khususnya pemanfaatan limbah genteng beton untuk paving block.

b. Dapat lebih meningkatkan kualitas pembangunan di Indonesia.

\section{Bahan-Bahan Campuran Beton}

Bahan-bahan yang digunakan untuk campuran beton paving block terdiri dari semen, agregat halus, air dan limbah genteng beton sebagai pengganti agregat kasar.

\subsection{Semen Portland}

Semen portland didefinisikan sebagai semen hidrolik yang dihasilkan dengan klinker yang terdiri dari kalsium silikat hidrolik yang umumnya mengandung satu atau lebih bentuk kalsium sulfat sebagai bahan tambahan, yang digiling bersama-sama bahan utamanya. Bahan utama penyusun semen adalah Kapur $(\mathrm{CaO})$, Silika ( $\mathrm{SiO} 3)$, alumina ( A12 O3). Fungsi utama semen pada beton adalah mengikat butir- butir agregat sehingga membentuk suatu massa padat. Selain itu juga untuk mengisi rongga-rongga udara di antara butir - butir agregat.

\subsection{Agregat Halus}

Agregat halus atau pasir merupakan batuan berbutir halus yang terdiri atas butiran sebesar $0,15 \mathrm{~mm}$ sampai $4,75 \mathrm{~mm}$. Pasir berasal dari penghancuran batuan baik secara alamiah maupun penghancuran dengan bantuan manusia. Pasir berfungsi antara lain sebagai bahan campuran adukan beton. Maka dari itu mutu dari pasir sangat perlu diperhatikan. Susunan besar butir agregat halus mempunyai modulus kehalusan antara 1.5 - 3.8 dan harus terdiri dari butir-butir yang beraneka ragam besarnya.

\subsection{Air}

Kualitas air yang digunakan untuk mencampur beton sangat berpengaruh terhadap kualitas beton itu sendiri. Air yang mengandung zat-zat kimia berbahaya, mengandung garam, minyak, dll dakan menyebabkan kekuatan beton turun. Pada umumnya air yang dapat diminum dapat digunakan sebagai campuran beton. Air yang berlebihan akan menyebabkan banyaknya gelembung air setelah proses hidrasi selesai. Apabila air terlalu sedikit akan menyebabkan proses hidrasi tidak tercapai seluruhnya, sehingga akan mempengaruhi kekuatan beton dan sulit untuk dikerjakan.

\subsection{Agregat kasar}

Agregat kasar adalah kerikil sebagai hasil desintegrasi alami dari bantuan atau berupabatu pecah yang diperoleh dari industri pemecah batu dan mempunyai ukuran butir antara $5 \mathrm{~mm}-40 \mathrm{~mm}$.[3]. Agregat kasar tidak boleh mengandung lumpur lebih dari 1\% dan Agregat kasar ini terdiri dari butir-butir yang beraneka ragam besarnya dan apabila diayak dengan susunan ayakan yang ditentukan, susunan besar butir mempunyai Nilai modulus kehalusan antara $6-7$. Butir-butir agregat kasar harus bersifat kekal 
artinya tidak pecah atau hancur oleh pengaruh-pengaruh cuaca, seperti terik matahari dan hujan serta Agregat kasar tidak boleh mengandung zat-zat yang dapat merusak beton, seperti zat-zat yang reaktif alkali.

Agregat Kasar yang dipakai dalam penelitian ini adalah Batu Split, yaitu satu jenis batu matrial bangunan yang diperoleh dengan cara membelah atau memecah batu yang berukuran besar menjadi ukuran kecil-kecil. Batu Split juga sering disebut dengan nama batu belah, karena disesuaikan dengan proses mendapatkannya yaitu dengan cara membelah batu. Genteng beton merupakan salah satu bahan yang memiliki daya tahan yang kuat karena dapat bertahan terhadap perubahan suhu dan api, serta mampu bertahan hingga kurun waktu yang lama. Limbah genteng beton yang digunakan disini dipecahkan terlebih dahulu sebelum digunakan untuk bahan campuran adukan dengan ukuran maksimal limbah genteng beton sebesar $10 \mathrm{~mm}$.

Penelitian terdahulu mengenai paving block yang menggunakan bahan pengganti flyash. Pada penggunaan fly ash $30 \%$ terhadap agregat, dikategorikan paving block mutu A yang dapat digunakan untuk perkerasan jalan.Kuat tekan yang dihasilkan adalah 33,582 $\mathrm{MPa} .4$ ] Penelitian mengenai komposisi batu pecah pada paving block, mendapatkan kuat tekan yang rendah, sebesar 14,36 Mpa dan 14,16 Mpa pada komposisi campuran antara semen, pasir dan batu pecah yaitu 1pc : 6 ps : 4bp.[5]

Adapun pengaruh ukuran butiran agregat terhadap kuat tekan dan modulus elastisitas beton kinerja tinggi. Kuat tekan beton dengan ukuran butiran yang lebih besar mempunyai nilai kuat tekan yang lebih rendah dibandingkan beton dengan ukuran butiran kecil. Peran gradasi agregat merupakan faktor yang harus diperhatikan. Susunan butiran (gradasi) yang baik dapat menghasilkan kepadatan (density) maksimum dan porositas (voids) minimum. Gradasi yang baik adalah gradasi yang menerus dimana seluruh ukuran butiran terdapat dalam agregat tersebut sehingga menciptakan butiran yang heterogen.[6]

Komposisi dalam penelitian ini adalah paving block dengan substitusi limbah genteng beton dalam perbandingan 1 PC : 3 Agregat ( kasar dan halus ) dengan 5 variasi. Adapun variasi yang digunakan terhadap pengganti agregat kasar dari $0 \%$ hingga $40 \%$ limbah genteng beton.

Tabel 2. Sifat Fisis Material Paving Block

\begin{tabular}{lclc}
\hline Sifat Bahan & $\begin{array}{c}\text { Jenis Bahan } \\
\text { (Kerikil) }\end{array}$ & $\begin{array}{c}\text { Agregat Kasar } \\
\text { (Limbah) }\end{array}$ & $\begin{array}{c}\text { Agregat Halus } \\
\text { (Pasir) }\end{array}$ \\
\hline Berat jenis SSD & 2,716 & 2,250 & 2,610 \\
Berat jenis asli & 2,682 & 2,041 & 2,599 \\
Berat isi lepas $\left(\mathrm{kg} / \mathrm{m}^{3}\right)$ & 1278,143 & 1236 & 1343,2 \\
Berat isi padat $\left(\mathrm{kg} / \mathrm{m}^{3}\right) 1422,286$ & 1295,2 & 1451,5 \\
Penyerapan air $(\%)$ & 1,2621 & 0,263 & 0,397 \\
Kadar air $(\%)$ & 0,854 & 2,688 & 6,840 \\
Analisa ayak & max. $9,5 \mathrm{~mm}$ & $\max .9,5 \mathrm{~mm}$ & Zone 2 \\
\hline
\end{tabular}




\section{METODE PENELITIAN}

Sebelum proses pengadukan dimulai beberapa material perlu dilakuan pengujian seperti:

a. Analisa ayak agregat halus dan kasar

b. Berat jenis agregat dan penyerapan air agregat halus dan kasar

c. Kadar air agregat halus dan kasar

d. Kadar lumpur agregat halus dan kasar

e. Berat isi agregat halus dan kasar

f. Analisa ayak limbah genteng beton

g. Berat isi limbah genteng beton

h. Kadar lumpur limbah genteng beton

i. Kadar air limbah genteng beton

j. Berat jenis dan penyerapan air limbah genteng beton

Limbah genteng beton dipecahkan menjadi agregat yang berukuran maksimum $10 \mathrm{~mm}$. Pemecahan dilakukan dengan cara manual ( memakai palu besi ) kemudian diayak dengan saringan lubang ayakan $9,5 \mathrm{~mm}$ dan yang digunakan adalah yang lolos dari ayakan tersebut.
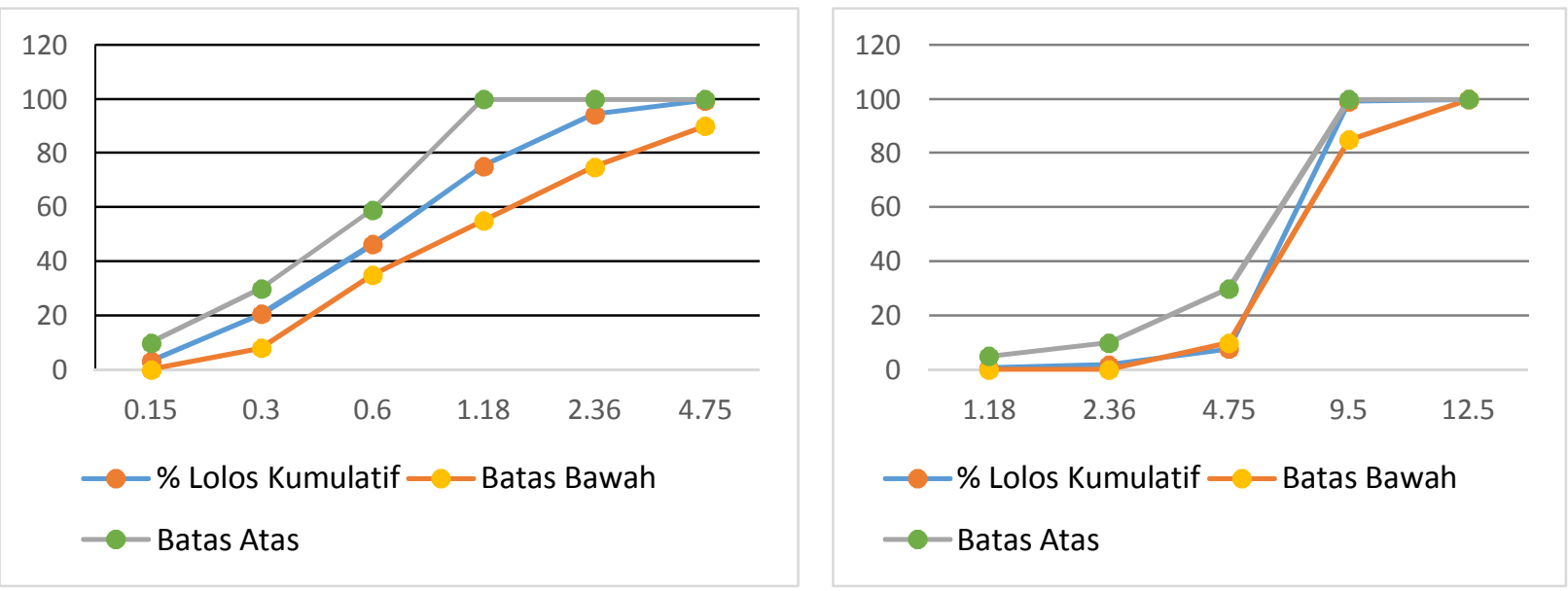

Gambar 2. Analisa Ayak Agregat Halus dan Agregat Kasar

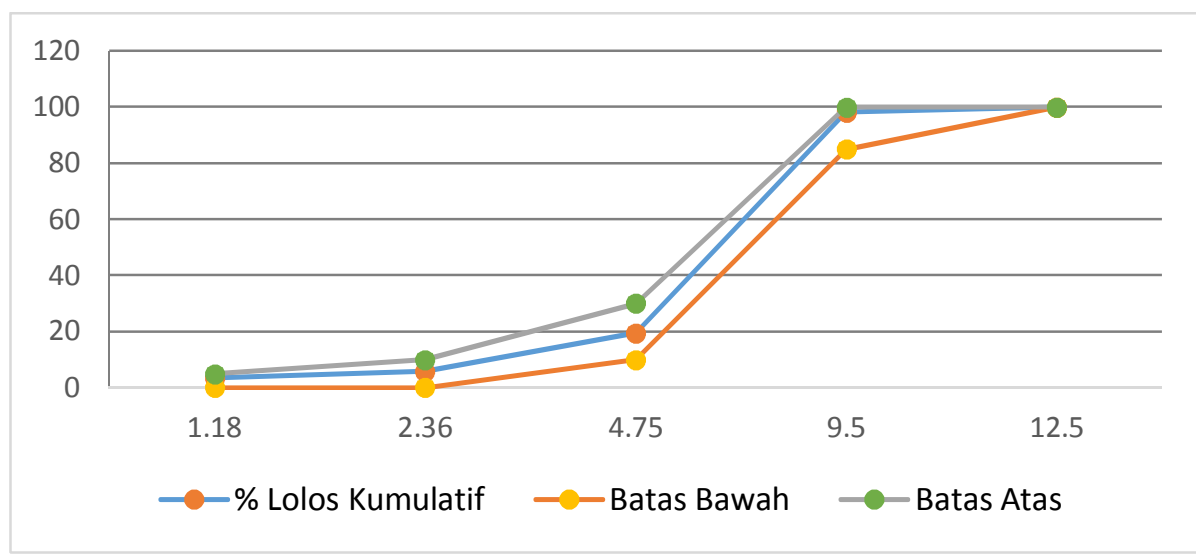

Gambar 3. Analisa Ayak Limbah Genteng 
Paving block press hidrolik. Paving jenis ini diproduksi dengan cara dipress (gambar 4) menggunakan mesin press hidrolik dengan kuat tekan diatas $300 \mathrm{~kg} / \mathrm{cm} 2$. Paving block press hidrolik dapat dikatagorikan sebagai paving block dengan mutu B-A. Pemakaian paving jenis ini dapat digunakan untuk keperluan non-struktural maupun untuk keperluan struktural yang berfungsi untuk menahan beban yang berat yang dilalui diatasnya, seperti areal jalan lingkungan hingga sebagai perkerasan lahan pelataran terminal peti kemas dipelabuhan.[7].
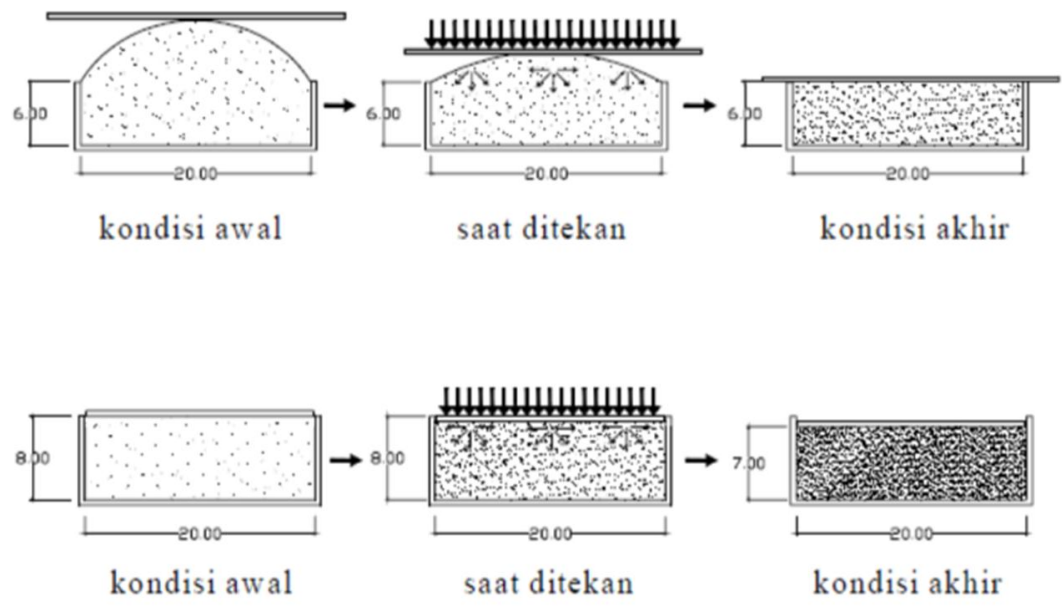

Gambar 4. prinsip kerja cetakan [8]

Pabrik U.D. Hasyim menggunakan jenis mesin cetak dengan sistem getar atau vibrasi. Mesin tersebut memiliki spesifikasi, diantaranya : panjang (1200 mm), lebar (900 mm), tinggi (1950 mm), penggerak (E.motor 3 phase), dan kapasitas 2000 pcs hari.

Pembuatan paving block cara mekanis dilakukan dengan menggunakan mesin (compression aparatus). Metode mekanis biasanya digunakan oleh pabrik dengan skala yang besar.

Benda uji dibuat dengan ukuran $21 \times 10,5 \times 6 \mathrm{~cm}$ dengan menggunakan mesin press hidrolik. Pembuatan benda uji paving block (tabel 3) menggunakan perbandingan volume campuran (1) PC : (3) Agregat pada FAS = 0,35 dengan variasi substitusi agregat kasar limbah genteng beton $0 \%, 10 \%, 20 \%, 30 \%$ dan $40 \%$.

Komposisi campuran yang digunakan ( resume hasil ) untuk 20 benda uji

Tabel 3. Pemakaian material paving block

\begin{tabular}{llllll}
\hline Material & $\mathbf{0 \%}$ & $\mathbf{1 0 \%}$ & $\mathbf{2 0 \%}$ & $\mathbf{3 0 \%}$ & $\mathbf{4 0 \%}(*)$ \\
\hline Semen & 15,96 & 16,09 & 16,06 & 16,04 & 9,61 \\
Kerikil & 17,43 & 15,81 & 14,04 & 12,27 & 6,30 \\
Pasir & 37,8 & 38,11 & 38,05 & 38,00 & 22,77 \\
Limbah & 0 & 1,42 & 2,84 & 4,26 & 3,40 \\
Air & 5,59 & 5,63 & 5,62 & 5,62 & 3,36 \\
\hline
\end{tabular}

Catatan : (*) untuk 12 benda uji 

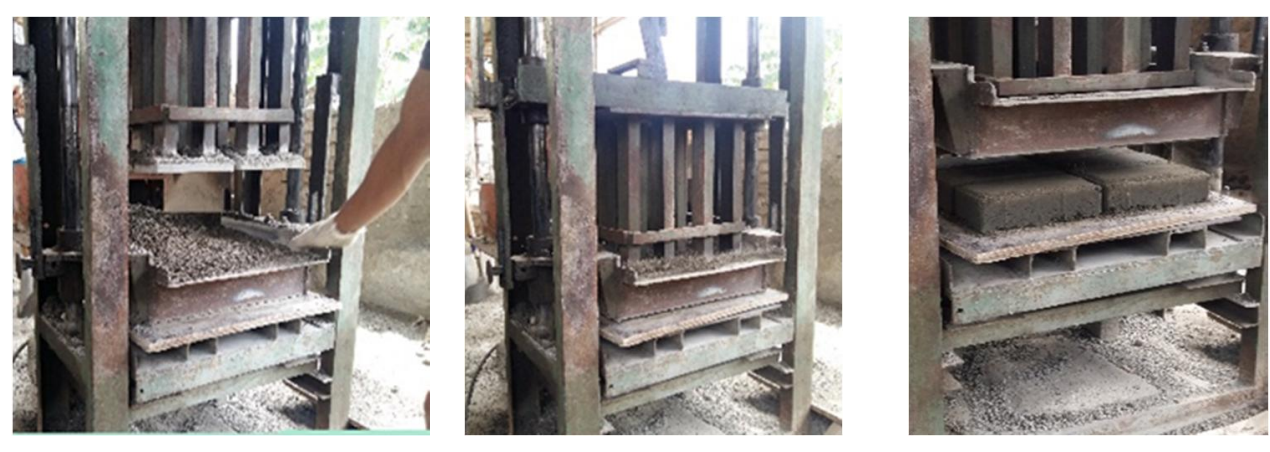

Gambar 5. Proses Cetak Paving Block

Langkah Penelitian Paving block



Gambar 6. Tahapan Penelitian 


\section{HASIL DAN PEMBAHASAN}

Tabel 4. Hasil Uji Kekuatan Tekan

\begin{tabular}{ccc}
\hline Variasi & \multicolumn{2}{c}{ Kuat Tekan MPa } \\
& $7 \mathrm{hr}$ & $28 \mathrm{hr}$ \\
\hline $0 \%$ & 52,6 & 62,8 \\
$10 \%$ & 41,7 & 45,0 \\
$20 \%$ & 39,5 & 42,8 \\
$30 \%$ & 38,6 & 40,6 \\
$40 \%$ & 26,0 & 28,9 \\
\hline
\end{tabular}



Gambar 7. Kuat Tekan7-28

Limbah genteng beton yang digunakan sebagai komposisi paving block adalah dalam bentuk agregat kasar bukan sebagai agregat halus. Jenis pasir tidak mempengaruhi kekuatan tekan beton [9]. Dari hasil uji tekan (gambar 7), hingga 30\% penggunaan limbah genteng beton didapatkan kekuatan rerata diatas $40 \mathrm{MPa}$ atau masuk pada mutu A dengan kategori untuk klas jalan. Untuk pemakaian limbah genteng diatas 30\% kekuatan tekan turun cukup besar.

Tabel 5. Penyerapan Air pada paving block didapatkan

\begin{tabular}{ccccccc}
\hline No & \multirow{2}{*}{ Variasi } & $\begin{array}{c}\text { Berat SSD } \\
\text { (gram) }\end{array}$ & $\begin{array}{c}\text { Berat Oven } \\
\text { (gram) }\end{array}$ & $\begin{array}{c}\text { Penyerapan } \\
\text { air (\%) }\end{array}$ & Rerata \\
\hline 1 & & A & 3038 & 2915 & 4,220 & \\
2 & $0 \%$ & B & 3044 & 2917 & 4,354 & 4,421 \\
3 & & C & 3214 & 3070 & 4,691 & \\
\hline 4 & & A & 3076 & 2906 & 5,850 & \\
5 & $10 \%$ & B & 3116 & 2951 & 5,591 & 5,476 \\
6 & & C & 3158 & 3008 & 4,987 & \\
\hline 7 & & A & 3310 & 3058 & 8,241 & \\
8 & \multirow{2}{*}{$20 \%$} & B & 3508 & 3278 & 7,016 & 6,365 \\
9 & & C & 3410 & 3284 & 3,837 & \\
\hline 10 & & A & 3390 & 3216 & 5,410 & \\
11 & $30 \%$ & B & 3418 & 3168 & 7,891 & 7,318 \\
12 & & C & 3190 & 2936 & 8,651 & \\
\hline 13 & \multirow{2}{*}{$40 \%$} & A & 2760 & 2549 & 8,278 & \multirow{2}{*}{8,024} \\
14 & & B & 2732 & 2535 & 7,771 & \\
\hline & & & & & & \\
\hline
\end{tabular}

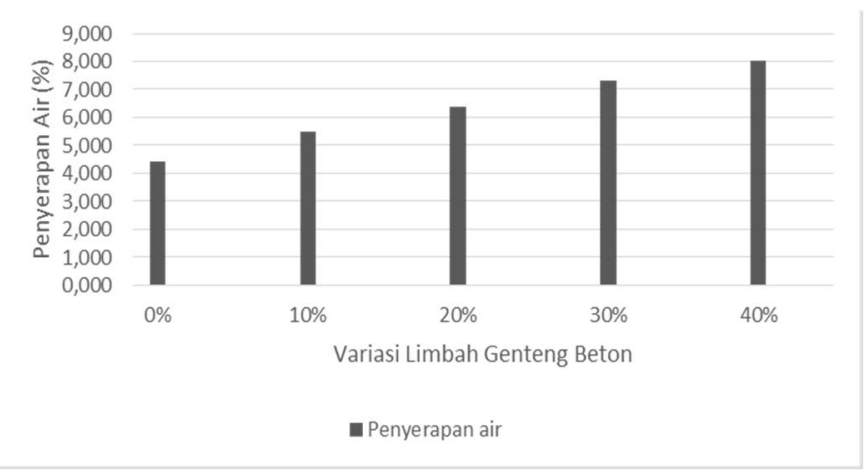

Gambar 8. Daya serap air 
Melihat hasil penyerapan air, semakin besar prosentase limbah genteng beton didapatkan nilai penyerapan air yang besar (gambar 8). Nilai penyerapan air 7\% didapatkan pada prosentase $30 \%$ limbah genteng beton dan termasuk mutu B. Nilai yang sama juga didapat dari presentase penyerapan air pada pembuatan paving block dengan $30 \%$ bottom ash batu bara. Pada umumnya nilai penyerapan air yang terjadi cukup besar[10]

\section{UCAPAN TERIMAKASIH}

Ucapan terima kasih kami ucap kepada Politeknik Negeri Jakarta khususnya jurusan teknik sipil, laboratorium Uji bahan dan juga U.D Hasyim yang berlokasi di Kali Mulya Depok yang sudah banyak membantu dan memberikan saran terhadap tulisan ini , Pemanfaatan Limbah Genteng beton pada Paving block.

\section{KESIMPULAN}

1. Bentuk / sifat tampak dan ukuran paving block dengan limbah genteng beton sebagai substitusi agregat kasar yang memiliki tebal nominal minimum $60 \mathrm{~mm}$ mempunyai permukaan yang rata, dan tidak terdapat cacat dan bagian sudut dan rusuk - rusuknya serta tidak mudah direpihkan dengan kekuatan jari tangan. Dengan demikian, paving block dengan limbah genteng beton memenuhi syarat mutu sifat tampak berdasarkan SNI 03 - 0691- 1996.

2. Limbah genteng beton mempunyai potensi yang cukup besar terhadap daya serap air sehingga rongga udara yang terjadi menjadi lebih besar. Penyerapan air pada paving block dengan limbah genteng beton sebagai substitusi agregat kasar di dapatkan prosentase nilai yang semakin naik dengan bertambahnya kadar limbah agregat kasar. Pada prosentase $0 \%-4,421 \%$ menjadi $8,024 \%$ pada prosentase $40 \%$ limbah genteng beton. Untuk prosentase sampai 30\% limbah dapat dikategorikan mutu B dan pada prosentase $40 \%$ adalah mutu C sesuai dengan SNI.

3. Pemakaian limbah genteng beton untuk paving block dapt menyebabkan penurunan kuat tekan namun tetap mengacu pada standar. Nilai kuat tekan umur 7hari dan 28 hari , dengan meningkatnya prosentase (0\%-40\%) agregat kasar limbah genteng beton, mengalami penurunan yaitu dari $52 \mathrm{MPa}$ hingga $26 \mathrm{MPa}$ (7 hari) dan mulai $63 \mathrm{MPa}$ hingga $29 \mathrm{MPa}$ (28 hari). Hal ini juga disebabkan oleh rongga udara yang terjadi akibat pemakaian limbah genteng. Untuk prosentase 0\%-30\% limbah dapat dikategorikan mutu A dan pada prosentase $40 \%$ adalah mutu B sesuai dengan SNI.

\section{DAFTAR PUSTAKA}

[1] Nadhiroh, Nasruri. 1992. Penelitian Pemanfaatan Limbah Industri Peleburan Timah Untuk Bahan Bangunan. J. Penelitian Pemukiman 1. VII : 43 - 51.

[2] SNI 03-0691-1996, Bata Beton (Paving block), Badan Standarisasi Nasional, Jakarta

[3] SNI 03-2847-2002), Persyaratan beton struktural untuk bangunan gedung, Badan Standarisasi Nasional, Jakarta 
[4] Mulyati, Maliar.S.,2015, Pengaruh penggunaan fly-ash sebagai pengganti agregat terhadap kuat tekan paving block, J Momentum, Vol 17 No.1. Februari 2015, ISSN:1693-752X, p 49

[5] Malissa .H., 2006, Pengaruh batu pecah terhadap kuat tekan paving block, jurnal.untad.ac.id, Vol 4, No 3, ISSN 1693-0460, p 157-165,Palu.

[6] Purwati, As'ad, Sunarmasto. 2014. Pengaruh Ukuran Butir Agregat Terhadap Kuat Tekan dan Modulus Elastisitas Beton Kinerja Tinggi Grade 80 [skripsi]. Surakarta : Universitas Sebelas Maret Surakarta

[7] Wintoko Bambang, 2012, Sukses Wirausaha Batako Dan Paving Block, Pustaka Baru Press: Pekan Baru.

[8] http://eprints.undip.ac.id/33843/6/1794_CHAPTER_II.pdf.

[9] Aini, N.,2014. Pengaruh Kuat Tekan Paving Block menggunakanPasir Sungai dan Pasir Darat, jurnal.pusjatan.pi.go.id, Puslitbang Kementrian PU.

[10]Wardono, A. Dan Tokedo, B, 2018. Pengaruh penggunaan Bottom Ash Batu Bara dan Limbah Karbit sebagai substitusi semen pada campuran Paving Block, Rekayasa Teknik Sipil Vol 1 Nomor 01/Rekat/2018, hal 40-48, Universitas Negeri Surabaya. 